2011-4

\title{
Comparison of Subcellular Responses for the Evaluation and Prediction of the Chemotherapeutic Response to Cisplatin in Lung Adenocarcinoma using Raman Spectroscopy
}

\author{
Haq Nawaz \\ Technological University Dublin, haq.nawz@tudublin.ie \\ Franck Bonnier \\ Technological University Dublin, Franck.Bonnier@tudublin.ie \\ Aidan Meade \\ Technological University Dublin, aidan.meade@tudublin.ie
}

See next page for additional authors

Follow this and additional works at: https://arrow.tudublin.ie/radart

Part of the Analytical, Diagnostic and Therapeutic Techniques and Equipment Commons, Biotechnology Commons, and the Medicinal Chemistry and Pharmaceutics Commons

\section{Recommended Citation \\ Bonnier, F. et al (2011) Comparison of subcellular responses for the evaluation and prediction of the chemotherapeutic response to cisplatin in lung adenocarcinoma using Raman spectroscopy" Analyst, 136, pp.2450-2463. doi:10.1039/c1an15104e}

This Article is brought to you for free and open access by the Radiation and Environmental Science Centre at ARROW@TU Dublin. It has been accepted for inclusion in Articles by an authorized administrator of ARROW@TU

Dublin. For more information, please contact

arrow.admin@tudublin.ie, aisling.coyne@tudublin.ie, gerard.connolly@tudublin.ie.

Funder: HEA TSR Strand III

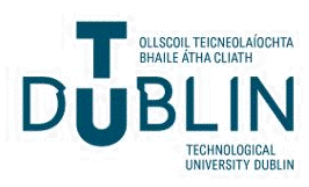




\section{Authors}

Haq Nawaz, Franck Bonnier, Aidan Meade, Fiona Lyng, and Hugh Byrne

This article is available at ARROW@TU Dublin: https://arrow.tudublin.ie/radart/31 


\title{
Comparison of subcellular responses for the evaluation and prediction of the chemotherapeutic response to cisplatin in lung adenocarcinoma using Raman spectroscopy
}

\author{
${ }_{5}$ Haq Nawaz $^{\mathrm{a}}$, Franck Bonnier ${ }^{\mathrm{b}}$, Aidan D. Meade ${ }^{\mathrm{a}, \mathrm{c}}$ Fiona M. Lyng ${ }^{\mathrm{a}}$, Hugh J. Byrne ${ }^{\mathrm{b}}$ \\ ${ }^{a}$ DIT Centre for Radiation and Environmental Science (RESC), Focas Research Institute, Dublin Institute of Technology, Kevin Street, \\ Dublin 8, Ireland \\ ${ }^{\mathrm{b}}$ Focas Research Institute, Dublin Institute of Technology, Kevin Street, Dublin 8, Ireland \\ ${ }_{10}{ }^{\mathrm{c}} \mathrm{School}$ of Physics, Dublin Institute of Technology, Kevin Street, Dublin 8, Ireland
}

*Corresponding Author: Haq Nawaz, DIT Centre for Radiation and Environmental Science (RESC), Focas Research Institute, Dublin Institute of Technology, Kevin Street, Dublin 8, Ireland, haq.nawaz@dit.ie

Received (in $X X X, X X X)$ Xth $X X X X X X X X X 200 X$, Accepted Xth $X X X X X X X X X 200 X$

${ }_{15}$ First published on the web $X$ th $X X X X X X X X X 200 X$

DOI: $10.1039 / b 000000 x$

\begin{abstract}
Confocal Raman Micro spectroscopy (CRM) is employed to examine the chemical and physiological effects of anticancer agents, using 20 cisplatin and A549 adenocarcinoma cells as a model compound and test system respectively. Spectral responses of the membrane and cytoplasm of the cell are analysed independently and the results are compared to previously reported spectroscopic studies of the nucleus. Moreover, Raman spectra from the proteins extracted from the control and exposed samples are acquired and analysed to confirm the origin of the molecular changes of the cell membrane and cytoplasm of the A549 cells. Multivariate data analysis techniques including Principal Component Analysis (PCA) and Partial Least Square Regression (PLSR) along with PLS-Jack knifing are used to analyse the 25 data measured from the cell membrane and cytoplasm of the A549 cells and results are correlated with parallel measurements from the cytotoxicity assay MTT. A PLSR model is used to differentiate between the chemical effect of the chemotherapeutic agent and the physiological response of the A549 cells and to identify regions of the spectrum that are associated with these processes respectively. The PLSR model is also employed to predict, on the basis of the Raman spectra, the effective dose as well as the level of physiological response, using spectra data from the cytoplasmic and cell membrane regions. The effectiveness of the models based on spectral datasets

30 from the cell membrane and cytoplasm is compared to similar models constructed using spectral data from the nuclear region as well as one combining spectral data from all regions. In all cases, higher prediction accuracy is found for regression against the cisplatin dose, and for both regression against dose and physiological response, nuclear data yields higher precision.
\end{abstract}




\section{Introduction}

The study of the interaction of anticancer agents with cancer cell model systems is considered to be very 5 important at the preclinical stage of the drug development process in order to establish the mechanism of action of the drug as well as the response of the cell to the chemotherapeutic agent. There is great need for the development and establishment of a non-invasive 10 analytical technique which not only can be used for the analysis of the binding mechanism of the anticancer agents to their targets but which can also analyse the biological processes of the cell which occur in response to the action of the drug and ultimately predict the drug efficacy. ${ }_{15}$ Confocal Raman Micro spectroscopy (CRM) has emerged as a viable analytical tool for the analysis of biological tissue ${ }^{1}$ and the effect of external agents on the cell ${ }^{1-5}$. The technique is being explored extensively for the analysis of biological systems because it is non-invasive, cost 20 effective, rapid, requires no sample labelling prior to analysis and gives high content information ${ }^{6}$. It is capable of investigating sub-cellular biochemical structures ${ }^{7,8}$ and has already been explored for the analysis of the interaction of a range of chemotherapeutic agents with ${ }_{25}$ biological macromolecules ${ }^{9}$ and with cancer cells ${ }^{6,10-12}$. In order to validate the technique of CRM for quantitative measurement of the biochemical and physiological effects of novel chemical treatments, it is necessary to demonstrate and evaluate the technique for anticancer 30 agents whose mechanism and efficacy of action is well known. The use of CRM for the analysis and prediction of the chemotherapeutic response of A549 cells to the action of the cisplatin (cis-Diamminedichloroplatinum (II)), based on analysis of the nuclear signals, has recently been ${ }_{35}$ demonstrated ${ }^{13}$. The use of both cisplatin dose, as well cellular response as defined by the cytotoxicity assay, MTT, as targets for PLS regression enabled a differentiation between the spectral changes associated with the direct chemical interaction with the nucleus and ${ }_{40}$ the resultant metabolic response.

It is also of great importance to understand and characterize the biochemical changes in the membrane and cytoplasm of cells during the course of the action of chemotherapeutic agents. These can occur due to the ${ }_{45}$ primary interactions during uptake of the agent, but also as a result of the subsequent cellular response. Cisplatin is widely used to treat a variety of cancers including lung, ovarian, colon, cervical, bladder, head and neck and testicular cancers, either as an individual agent or in ${ }_{50}$ combination with other drugs ${ }^{14-17}$. Its mechanism of chemical interaction is well characterised. While entering the cell, cisplatin interacts with lipids of the cell membrane which may affect the function of the cell membrane ${ }^{18}$, while inside the cytoplasm, it may bind to RNA and thiol ${ }_{55}$ groups of peptides and proteins ${ }^{19}$. In the cytosol, binding of cisplatin with some proteins may lead to the development of cytoxicity and resistance ${ }^{20}$. In the nucleus, it binds with DNA forming inter-strand and intra-strand crosslinks which lead to cell cycle arrest and apoptosis, the 60 primary cytotoxicological response ${ }^{21}$.

In the current study, the capabilities of CRM for the elucidation of the mechanism and efficacy of chemotherapeutic agents are further evaluated by exploring the spectral changes in the cell membrane and cytoplasm, ${ }_{65}$ using cisplatin and A549 adenocarcinoma cells as a model compound and test system respectively. Spectra of the cell membrane and cytoplasm of A549 cells were taken after a 96 hour exposure period to the agent, and multivariate models of the variation in spectral content with levels of 70 exposure and degrees of cytotoxicological response, as determined by the MTT assay were constructed. A feature selection technique was then used to identify regions of the spectrum that were associated with the biochemical effect of exposure to the agent, and with the subsequent 75 cytotoxicological response of the cells. Finally, multivariate Partial Least Squares Regression is used to demonstrate the capabilities of Raman spectral analysis to predict both the exposure dose and viability of the cell culture and results are compared to those previously 80 reported for spectroscopic analysis of the nuclear regions only $^{13}$.

\section{Materials and methods}

\section{${ }_{85}$ Cell culture}

A549 human lung adenocarcinoma cells were obtained from ATCC (CCL-185). The cells were cultured in DMEM F-12 (Sigma Aldrich, Ireland) medium supplemented with $9010 \%$ FBS, $1 \mu \mathrm{g} / \mathrm{ml}$ hydrocortisone (Sigma), $2 \mathrm{mM} \mathrm{L-}$ glutamine (Gibco) and $1 \%$ penicillin- streptomycin (Gibco). Cells were incubated at $37^{\circ} \mathrm{C}$ in $5 \% \mathrm{CO}_{2}$ and routinely subcultured with a $1: 1$ ratio of $0.25 \%$ trypsin and $0.1 \%$ EDTA when they reached $70-80 \%$ confluency.

95

\section{Cell exposure and cytotoxicity assay}

Cisplatin, obtained from Sigma Aldrich, Ireland, was dissolved in $1 \% \mathrm{NaCl}$ (Sigma Aldrich, Ireland) solution $100(\mathrm{pH} \mathrm{7})$ to prepare the stock solution. Working solutions of the drug were prepared in cell culture media. A 96-hour period of exposure to cisplatin was chosen along with a wide range of exposure concentrations ranging from 0.05 $50 \mu \mathrm{M}$, as this covers the range of the cytotoxic response 105 and provided a dataset upon which to base a regression model to demonstrate the predictive ability of the Raman spectral measurements. Cytotoxicity was measured according to the MTT [3-(4,5-dimethylthiazol-2-yl)-2,5diphenyl tetrazolium bromide] assay, obtained from Sigma 110 Aldrich, Ireland. MTT is a molecular assay whose colour is changed by mitochondrial reductases in living cells, and it is therefore commonly used as an indicator of cell viability and proliferative capacity and thus the cytotoxicity of chemical agents. 
The MTT assay was performed in triplicate according to a method reported previously ${ }^{22}$ with a slight modification ${ }^{13}$. Cells were cultured in 96-well plates (Nunc, Denmark) at a ${ }_{5}$ density of $2 \times 10^{3}$ cells per well in DMEM-F12 medium with all the supplements as listed above. After $24 \mathrm{hrs}$ of initial cell attachment, the plates were washed with 100 $\mu \mathrm{l} /$ well phosphate buffered saline (PBS) and were treated with varying concentrations of cisplatin in the range from ${ }_{10} 0.05 \mu \mathrm{M}-50 \mu \mathrm{M}$ (including a separate unexposed control sample). Following a 96-hour exposure period, the cells were rinsed with PBS and $100 \mu$ of fresh medium (without supplements) were added to each well. A volume of $10 \mu \mathrm{l}$ of MTT $(5 \mathrm{mg} / \mathrm{ml})$ prepared in PBS was then added to each 15 well and the plates were incubated for $3 \mathrm{hrs}$ at $37{ }^{\circ} \mathrm{C}$ in a $5 \% \mathrm{CO}_{2}$ humidified incubator. After this incubation period, the medium was discarded, the cells were washed with 100 $\mu \mathrm{l}$ of PBS and $100 \mu \mathrm{l}$ of DMSO was added to each well to extract the dye. The plates were then shaken 240 times per 20 minute for $10 \mathrm{~min}$ and the absorbance was measured at 570 $\mathrm{nm}$ using a micro plate reader (Tecan Genios, Grodig, Austria). Six replicate wells were used for each exposure.

\section{Protein extraction}

25

The cellular protein was extracted from both a control sample of A549 cells together with a sample of A549 cells exposed to $3 \mu \mathrm{M}$ cisplatin for 96 hours. The $3 \mu \mathrm{M}$ exposure level was chosen as it provided the means to 30 examine the ability of CRM to identify relatively small levels of changes in protein, structural and conformational, as a result of cisplatin binding. As determined using the cytotoxicity assay, at this concentration, the viability has reduced to approximately $30 \%$ and thus it represents the 35 inverse exponential point of the response. Briefly, cells were trypsinised and centrifuged to form a pellet of cells, and $1 \mathrm{ml}$ TRIzol reagent (Invitrogen) per $5-10 \times 10^{6}$ cells was added. The samples were then homogenized and incubated at room temperature for $5 \mathrm{~min}$ to induce cell 40 lysis. For each $\mathrm{ml}$ of TRIzol reagent, $200 \mu \mathrm{l}$ of chloroform was added and samples were centrifuged at $12,000 \times g$ for 5 min at $4{ }^{\circ} \mathrm{C}$. Following centrifugation, the mixture separated out into a lower red organic phase, a thin interphase and a colourless upper aqueous phase. Then 300

${ }_{45} \mu \mathrm{l}$ of $100 \%$ ethanol per $\mathrm{ml}$ of TRIzol reagent was added to the interphase and organic phase followed by mixing and spinning which yielded a pellet and supernatant. The supernatant was used to extract the proteins. To precipitate proteins, $1.5 \mathrm{ml}$ of isopropanol $/ \mathrm{ml}$ of Trizol reagent used 50 was added for initial homogenization. The samples were stored at room temperature for 10 minutes and sedimented by centrifugation at $12000 \mathrm{xg}$ for $10 \mathrm{~min}$. and $4{ }^{\circ} \mathrm{C}$. The supernatant was removed and the protein pellet was washed three times with $0.2 \mathrm{M}$ guanidine thiocyanate to 55 remove phenol and dye. After the final wash, the protein pellet was vortexed in $2 \mathrm{ml} 100 \%$ ethanol and was stored in ethanol for 20 minutes at room temperature. After that, the pellet was air dried and dissolved in 1\% SDS (Sodium
Dodecyl Sulphate) and then incubated at $50{ }^{\circ} \mathrm{C}$, to extract ${ }_{60}$ the proteins from the pellet. The insoluble material was sedimented by centrifugation at $10,000 \mathrm{~g}$ for $10 \mathrm{~min}$. at 4 ${ }^{\circ} \mathrm{C}$ and the supernatant containing total cellular proteins was transferred into a clean tube. To get the proteins in pellet form from this supernatant, acetone precipitation of ${ }_{65}$ the proteins was performed. To do this, equal volumes of the ice-cold acetone was added to the protein supernatant and incubated on ice for 15 minutes followed by the centrifugation for $10 \mathrm{~min}$. at $12000 \mathrm{x} \mathrm{g}$ in a pre-cooled microcentrifuge at $4 \dot{\mathrm{c}}$. The supernatant was discarded and 70 pellet was air dried. In order to verify the purity of the proteins, the absorbance of the sample was recorded on a $\mathrm{UV}-\mathrm{Vis}$ spectrophotometer at $260 \mathrm{~nm}$ and $280 \mathrm{~nm}$. A ratio of 0.6 (A260/A280) is characteristic of pure protein. The pellet was dissolved in $\mathrm{dH}_{2} \mathrm{O}$, as water has a significantly 75 weaker Raman signal than common organic solvents, and was used immediately for analysis by Raman spectroscopy.

\section{Sample preparation for Confocal Raman Spectroscopy}

80

For CRM, cell samples were cultured on quartz substrates according to a protocol outlined elsewhere ". Briefly, quartz coverslips were coated with a $2 \%$ w/v gelatin-water solution and maintained at $4{ }^{\circ} \mathrm{C}$ for $6 \mathrm{hrs}$ to allow 85 polymerization of the gelatin to the substrate. Subsequently, $2.5 \times 10^{3}$ A549 cells were attached to the substrates for a 48 hour period, and were exposed to the cisplatin concentrations in the range $0.05 \mu \mathrm{M}-50 \mu \mathrm{M}$ for a 96-hour period (together with a non-exposed control ${ }_{90}$ sample). After the exposure period, the cells were fixed in $4 \%$ formalin for 10 minutes and were stored in $0.9 \%$ physiological saline solution at $4{ }^{\circ} \mathrm{C}$ until the Raman analysis was performed ${ }^{5}$. Fixing the cells allows prolonged periods of storage and measurement. In a ${ }_{95}$ previous study, it has been demonstrated that although all commonly employed fixatives result in some degree of nucleic acid degradation, protein denaturation, and lipid leaching, fixing in formalin, in comparison to other fixatives, best preserves the integrity of the cells compared 100 to live cells. ${ }^{5}$ All samples were prepared in triplicate.

\section{Spectral Acquisition}

CRM was conducted with a Horiba Jobin-Yvon, LabRam ${ }_{105} \mathrm{HR} 800$ instrument using a $785 \mathrm{~nm}$ laser as source. The laser power was approximately $70 \mathrm{~mW}$ at the sample. Spectra were taken in the range from $600 \mathrm{~cm}^{-1}$ to $1800 \mathrm{~cm}$ ${ }^{1}$ with a confocal hole diameter of $100 \mu \mathrm{m}$. A $\times 100$ water immersion objective was used to focus the laser on the 110 sample, immersed in $0.9 \%$ saline. The spatial resolution of the instrument has previously been checked by performing a linescan of $1 \mu \mathrm{m}$ Iron oxide particles with a $0.2 \mu \mathrm{m}$ step size, which produced a profile of $1.5 \mu \mathrm{m}$ FWHM, implying a spotsize of $1.12 \mu \mathrm{m}^{7}$.Multiple spectra were recorded from 115 the cell membrane and cytoplasm portion and nucleus for a previously reported study ${ }^{13}$ of a total of 60 cells at each 
cisplatin exposure level, by performing a line scan across each cell as illustrated in Figure 1(a). Each scan was set up by initially focussing on the nucleus of the cell. Subsequently, the spectra were filtered with a Savitsky${ }_{5}$ Golay filter (order 5, 13 point window), and the quartz signal background was subtracted using algorithms developed in-house. Prior to analysis, the spectra were also vector normalized. For the acquisition of the spectra from the extracted protein, the protein dissolved in water was

${ }_{10}$ drop cast onto quartz substrates immediately prior to measurement.

\section{Data analysis}

All spectral analysis was performed in the Matlab 7.2 (The ${ }_{15}$ Mathworks Inc.) environment employing the PLS Toolbox 5.0.3 (Eigenvector Research, Wenatchee, WA) and algorithms developed in-house. Outlying spectra were removed using Grubb's filtering ${ }^{23}$. All spectra, including calibration and substrate backgrounds, were vector 20 normalized. The substrate spectra were subtracted from each spectrum and a fifth order polynomial was fitted to and subtracted from the spectra to remove any residual spectral baseline. Multivariate regression models were constructed using Partial Least Squares Regression (PLSR) ${ }_{25}{ }^{24}$ and PLS Jack-knifing was employed as a multivariate feature selection technique ${ }^{25-27}$. The PLSR algorithm seeks to develop a model that relates the spectral data (X-matrix) to a series of targets ( $Y$-matrix, e.g. concentration of reaction product or analyte) according to the equation ${ }_{30} Y=X B+E$, where $B$ is a matrix of regression coefficients and $E$ is the regression residual. The Y-matrix here consisted of values of the concentration of cisplatin to which the cell was exposed, or the measured level of cell viability from the MTT assay. The PLS Jack-knifing 35 method developed by Martens and colleagues was then used to determine the spectral features that were statistically significant at a particular level of confidence using t-testing of the regression coefficients, $B .{ }^{27}$. The Raman band assignments used in interpretation of the 40 spectral features were taken from the literature ${ }^{28-32}$.

\section{Results and Discussion}

\section{Comparison of the mean control spectra of the cell 45 membrane, cytoplasm and nucleus}

The mean control spectra of the cell membrane, cytoplasm and nucleus of A549 cells are shown in Figure 1(b). The mean control spectra of all the three cellular components 50 appear similar to the naked eye. In a similar analysis of live cells using K-means clustering, the nuclei, cytoplasm and membrane were clearly differentiated and spatially located, but the average K-cluster spectra showed similarly few identifiable spectral differences ${ }^{7}$. This is perhaps not ${ }_{55}$ surprising as, with a $1 \mu \mathrm{m}$ spot size, the nucleus can be specifically targeted, but the overlying cellular membrane and cytoplasm will also contribute to the spectrum acquired. Similarly, the spectrum of the cytoplasm will contain contributions from the overlying cellular ${ }_{60}$ membrane and potentially also from subcellular organelles such as mitochondria, lysosomes, etc., and inevitably the spectra of the cell membrance will contain contributions from the neighbouring cytoplasm.

Careful analysis of the spectra reveals however some ${ }_{65}$ differences which distinguish the spectra of the cell membrane and cytoplasm from the nucleus as demonstrated by the scatter plot of the Principal Component Analysis (PCA) shown in Figure 2(a). There is very good separation indicating that the spectra for the ${ }_{70}$ three cellular components are different and these experimental settings can be used for acquiring reliable spectra from the samples. The cellular regions are effectively separated according to PC1 which accounts for $95.58 \%$ of the variance and the spectral loadings are 75 illustrated in Figure 2(b). The Raman bands which differentiate the mean control spectra of the three cellular components are indicated by arrows (and by solid lines in Figure 1(b)) and these are also bands in which changes due to the action of the cisplatin are expected. The band at ${ }_{80} 726 \mathrm{~cm}^{-1}$, which can be assigned to tryptophan and/or $\mathrm{CH}_{3}$ stretching of the lipids, is present in the cytoplasm and cell membrane spectra but is not prominent in the nuclear spectra. The Raman band at $1423 \mathrm{~cm}^{-1}$ is assigned to $\mathrm{CH}_{3}$ deformation of aromatic lipids and is present in the spectra 85 of the cell membrane and cytoplasm but is similarly not prominent in the spectra of the nucleus. Another band at $1510 \mathrm{~cm}^{-1}$, assigned to $\mathrm{C}=\mathrm{C}$ stretching of proteins (Tryptophan, Tyrosine amino acids), is present in the mean spectra of the membrane and cytoplasm but absent in the 90 nuclear mean spectra. The two Raman bands which are present in all three mean spectra, indicated by dotted lines, correspond to $\mathrm{C}-\mathrm{H}$ deformation of lipids/proteins (1449 $\mathrm{cm}^{-1}$ ) and the amide-I band for proteins $\left(1660 \mathrm{~cm}^{-1}\right)$. Due to the action of the cisplatin, changes in these bands are 95 also expected.

For the nuclear mean spectra, the important Raman peaks which are different from the spectra of the cytoplasm and cell membrane are labelled. The Raman band at $718 \mathrm{~cm}^{-1}$ can be assigned to adenine while the bands at $807 \mathrm{~cm}^{-1}$ and $100827 \mathrm{~cm}^{-1}$ are assigned solely to O-P-O stretching of the DNA-A and B-form respectively and that at $1065 \mathrm{~cm}^{-1}$ assigned to the O-P-O stretching of the DNA backbone in general. These three Raman markers of the DNA backbone are present in the spectra of the nucleus with much higher 105 intensity as compared to the spectra of the cytoplasm and membrane. The Raman bands at $669 \mathrm{~cm}^{-1}$ (Thymine) and $1336 \mathrm{~cm}^{-1}$ (Guanine) are present, both in the mean spectra of the nucleus and cytoplasm which is expected, as their presence in the cytoplasm may be due to cytoplasmic ${ }_{110}$ DNA, and are unexpectedly seen in the membrane spectra which may be the contribution from the surrounding cytoplasm $^{29}$.

Comparing the mean control spectra of the nucleus of A549 cells with that of the cell membrane and cytoplasm, 115 ideally, there should be no peaks in the nuclear spectra for the lipids ( $\mathrm{CH}$ deformation, $1449 \mathrm{~cm}^{-1}$ ) but their presence 
may be due to the contribution from the surrounding cytoplasm ${ }^{33}$ and ${ }^{29}$ or on the other hand this band can be assigned, both to lipids and proteins ${ }^{34}$.

\section{${ }_{5}$ Cytotoxicity of cisplatin}

The dose response curve representing the cytotoxic response of cisplatin to A549 cells after $96 \mathrm{hrs}$ is presented in Figure $\mathbf{3}$ (reproduced from results published ${ }_{10}$ elsewhere $)^{13}$, where the level of viability in each sample was normalised to that in the control sample. Due to the action of the drug, the mitochondrial activity decreases monotonically which in turn leads to a decrease in cell viability. The Inhibitory Concentration $\left(\mathrm{IC}_{50}\right)$ value was 15 derived from the data by a fit of $\mathrm{f}(\mathrm{x})=\min +(\max -$ $\min ) /\left(1+\left(\mathrm{x} / \mathrm{IC}_{50}\right)^{\wedge} \mathrm{n}\right)$ and found to be $1.2 \pm 0.2 \mu \mathrm{M}$, which is consistent with the literature. For A549 cells exposed to test drug concentration (TDC) for $72 \mathrm{hrs}, \mathrm{IC}_{50}$ values of $3.59 \mu \mathrm{M}$ and $2.2 \mu \mathrm{M}$ are reported elsewhere with MTT and ${ }_{20}$ ATP assays respectively ${ }^{35}$. Also, Cordes et al. have determined an $\mathrm{IC}_{50}$ value of $2.0 \mu \mathrm{M}$ for cisplatin (0.1-50 $\mu \mathrm{M})$ exposed A549 cells using the colony formation assay 36 .

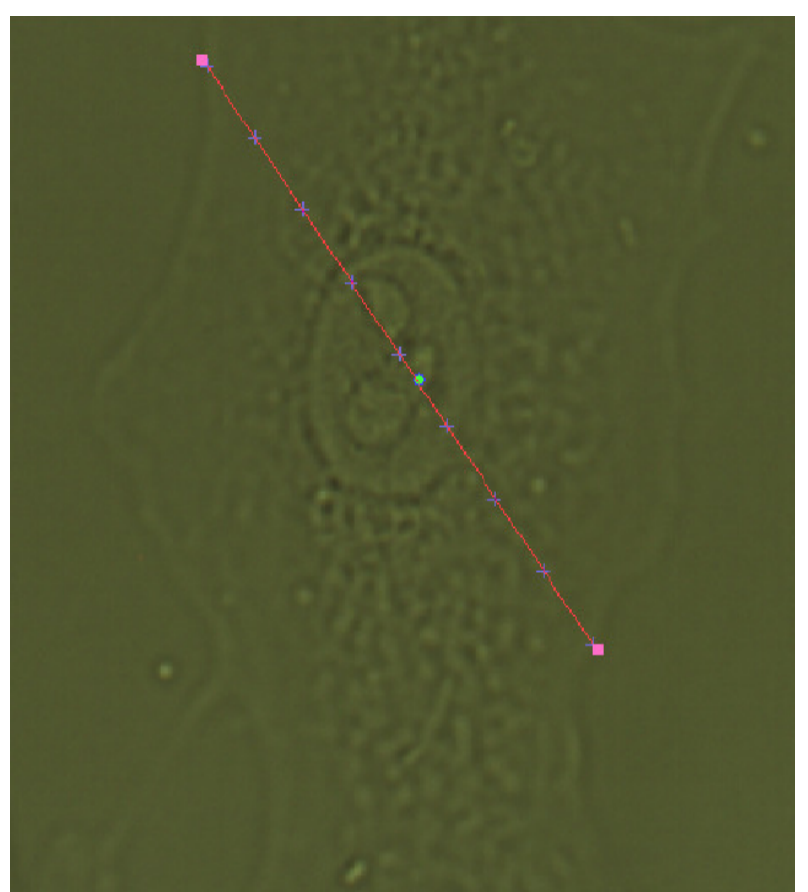

Figure 1 a: Image of an A549 cell (control) showing the range of a typical line map, as well as the points at which Raman spectra were recorded.

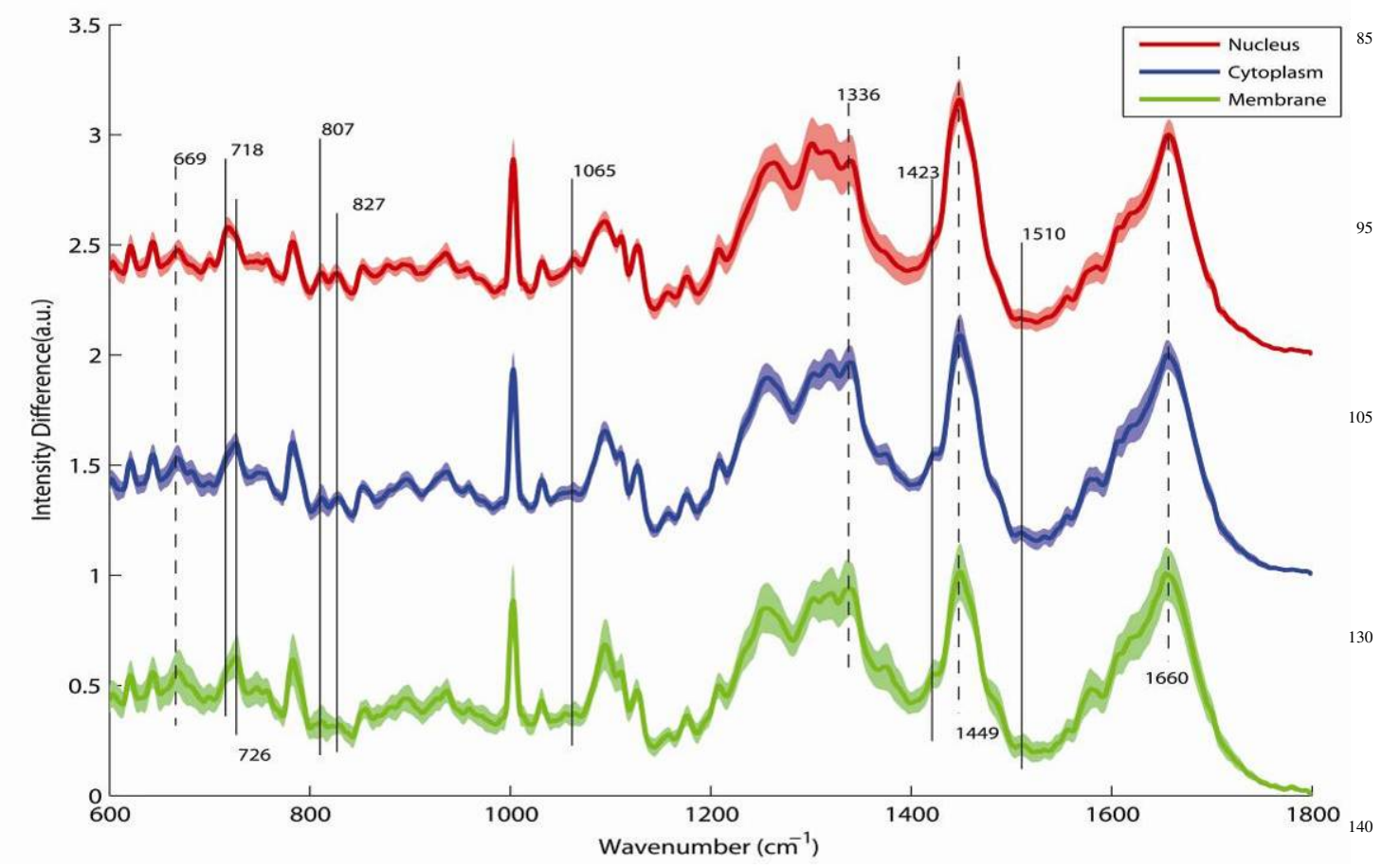

Figure 1 b: Mean control spectra of the (nucleus, cytoplasm and cell membrane) of A549 cells, the spectra are normalized and off set for clarity and shading shows the error bars. 


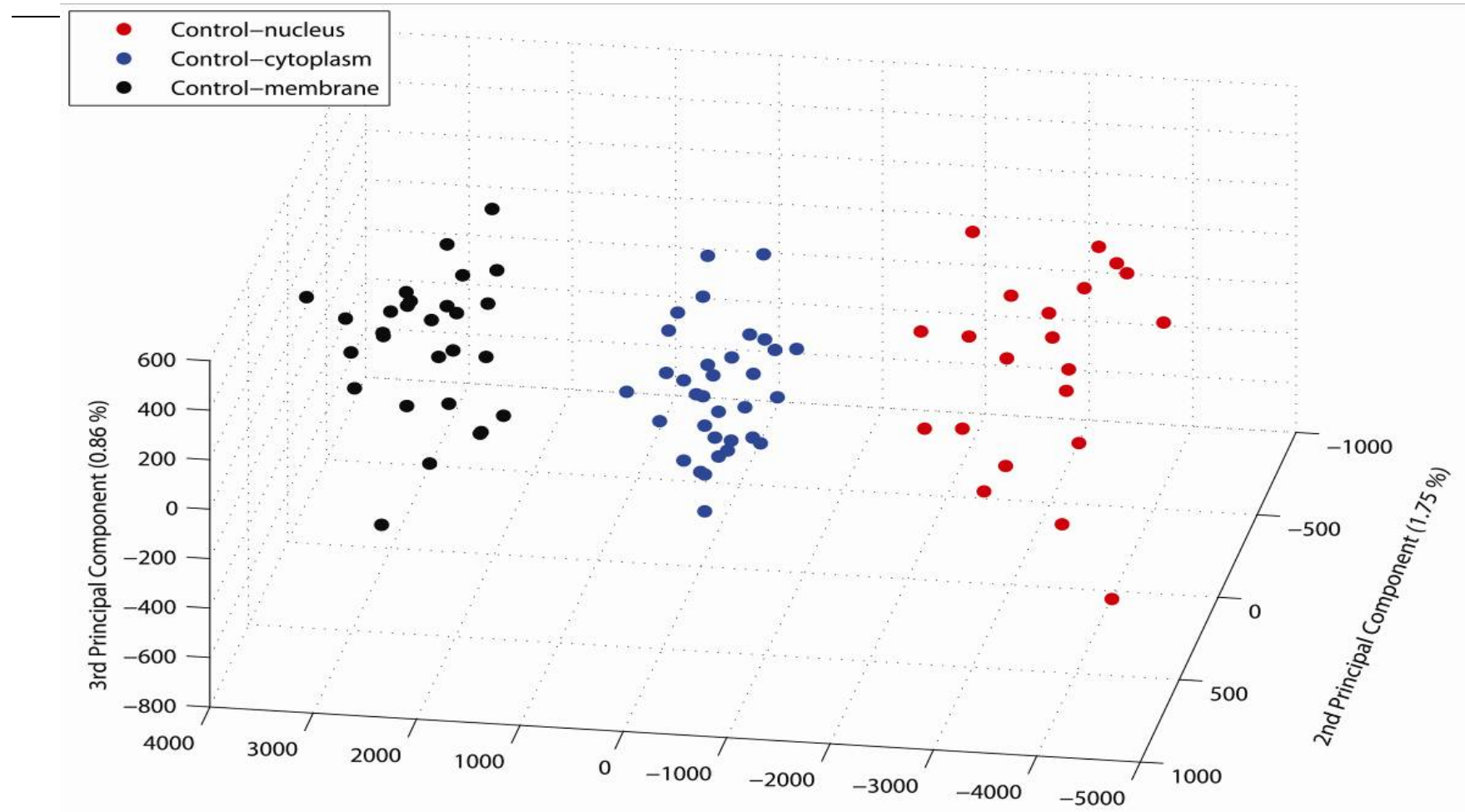

1st Principal Component (95.58\%)

Figure 2 a: Scatter plot of the Principal Component Analysis of the spectra of the nucleus, cytoplasm and cell membrane of control A549 cells

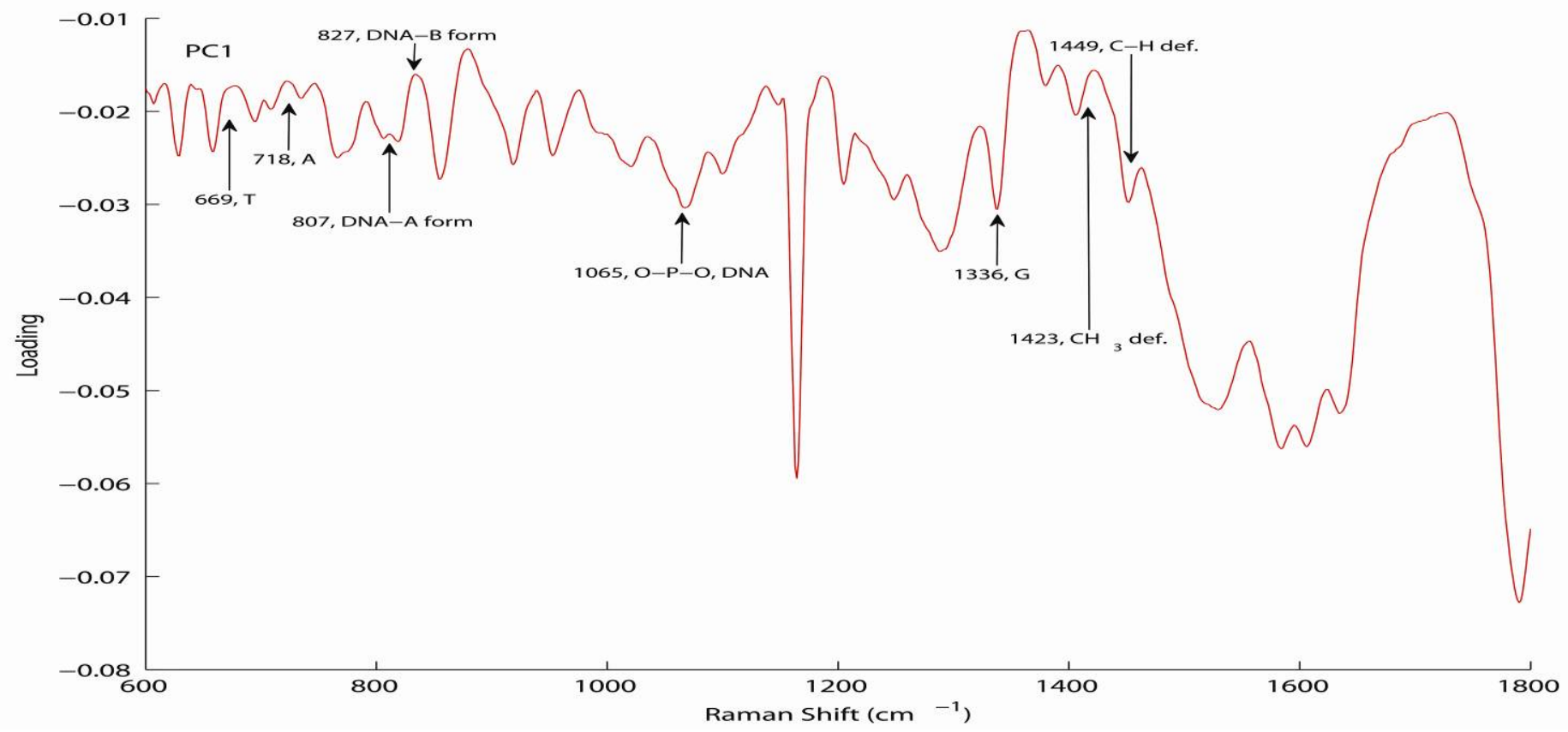

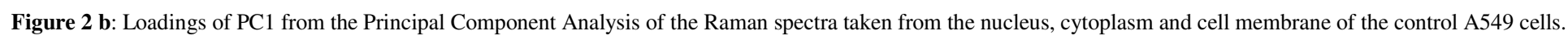




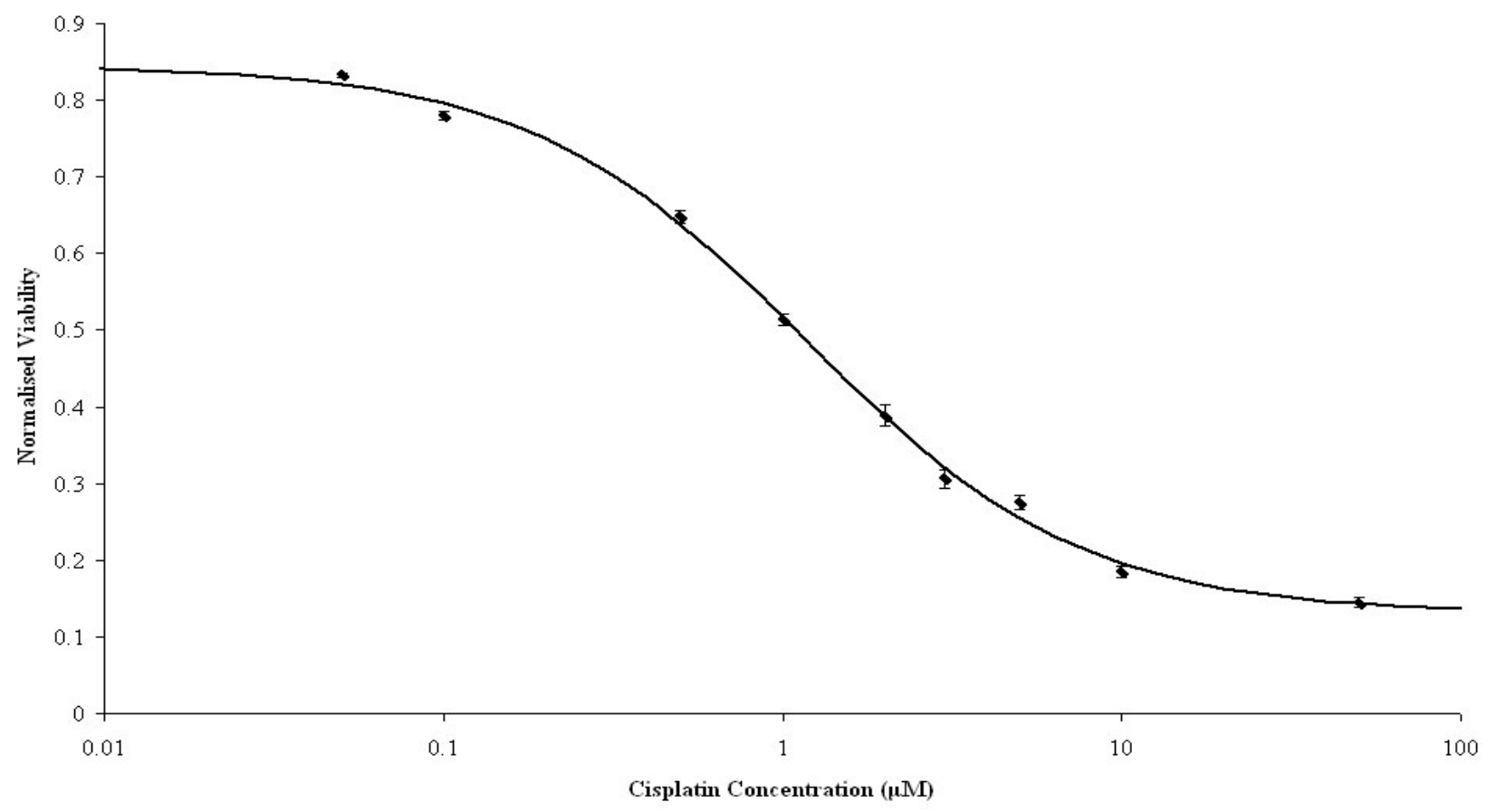

Figure 3: A549 cell viability (measured by MTT absorbance) at 96 hours after exposure to Cisplatin. Error bars denote the standard error on the mean at each concentration.

\section{Effect of cisplatin exposure on the spectra of cell membrane}

${ }_{30}$ Figure 4 shows the mean control (A) and difference spectrum of the cell membrane (B) of A549 cells exposed to $3 \mu \mathrm{M}$ cisplatin versus its control. It should be noted that no significant contributions due to the cisplatin itself are expected, as its Raman spectrum is dominated by bands in 35 the region between 100-550 $\mathrm{cm}^{-1}$ (Nawaz et al., 2010), which does not fall within the $600-1800 \mathrm{~cm}^{-1}$ spectral window of the current measurements. The most prominent changes are observed in the bands related to proteins at $671 \mathrm{~cm}^{-1}$ and $728 \mathrm{~cm}^{-1}$ (ring breathing of the tryptophan), $401030 \mathrm{~cm}^{-1}$ (C-H bending), $1094 \mathrm{~cm}^{-1}$ and $1126 \mathrm{~cm}^{-1}$ (C-N stretching) and $1655 \mathrm{~cm}^{-1}$ (amide-I). In addition to this, shifts in some of the Raman bands are also observed, including 1094 to $1097 \mathrm{~cm}^{-1}$ and 1126 to $1129 \mathrm{~cm}^{-1}$ (C-N stretching) and $1655-1659 \mathrm{~cm}^{-1}$ (amide-I) as labelled in the 45 mean difference spectra.

The Raman bands at $1371 \mathrm{~cm}^{-1}\left(\mathrm{CH}_{3}\right.$ stretching $)$ and 1448 $\mathrm{cm}^{-1}$ (CH deformation), related to cell membrane lipids, also undergo shifts from 1371 to $1376 \mathrm{~cm}^{-1}$ and 1448 to $1450 \mathrm{~cm}^{-1}$. These spectral changes and shifts in the Raman 50 signatures of the membrane proteins and lipids are consistent with the well known direct interaction of cisplatin ${ }^{37}$ and may also provide indications of the indirect action of the agent on cellular function ${ }^{18}$.

\section{Mean control and difference spectra of the cytoplasm}

${ }_{85}$ The mean control and difference spectra of the cytoplasm of A549 cells exposed to $3 \mu \mathrm{M}$ cisplatin are shown in Figure $5 \mathbf{A}$ and $\mathbf{B}$ respectively. The bands in which the major changes are observed are related to proteins, and include $671 \mathrm{~cm}^{-1}, 728 \mathrm{~cm}^{-1}, 1210 \mathrm{~cm}^{-1}$ (Tryptophan ring 90 breathing), $939 \mathrm{~cm}^{-1}$, (C-C skeletal stretching, á-helix), $1129 \mathrm{~cm}^{-1}$ (C-N stretching), $1179 \mathrm{~cm}^{-1}$ (C-H bending, Tyrosine), $1260 \mathrm{~cm}^{-1}$ (amide-III, $\beta$-sheets) and $1658 \mathrm{~cm}^{-1}$ (amide-I) along with shifts in some bands like 671 to 674 $\mathrm{cm}^{-1}, 728$ to $731 \mathrm{~cm}^{-1}$, (Tryptophan ring breathing), 1260 to ${ }_{95} 1265 \mathrm{~cm}^{-1}$ (amide-III, $\beta$-sheets) and 1658 to $1661 \mathrm{~cm}^{-1}$ (amide-I) as labelled in the mean difference spectra. These changes can be important Raman signatures of the binding of the cisplatin with the proteins in the cytoplasm of the cell ${ }^{19}$ which may lead to the development of cytoxicity 100 and resistance ${ }^{20}$ and cause changes in their secondary and tertiary structures.

\section{Spectra of extracted protein}

105 In order to further confirm the Raman markers for the direct chemical action of cisplatin and the cytotoxic response of the A549 cells to the cisplatin exposure from the cell membrane and cytoplasm, the spectra recorded of the protein extracted from the control and exposed $(3 \mu \mathrm{M}$ 110 for comparison to the spectroscopic analyses of the cells) A549 cells were analyzed. The mean control and the difference spectra of the extracted protein are shown in 

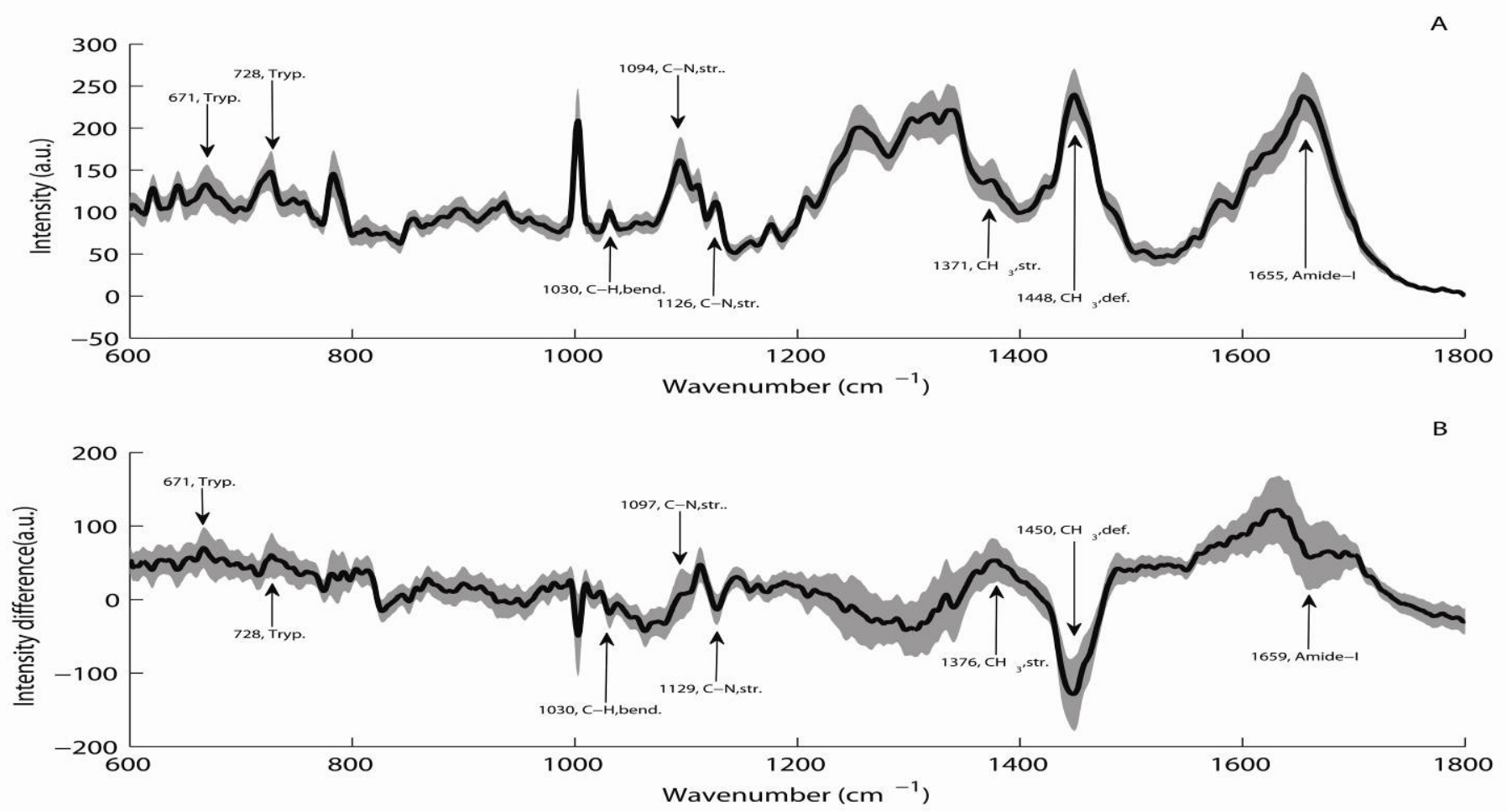

Figure 4: Mean spectrum of the cell membrane of control sample (A) and the difference spectrum (B) between the mean of the control and the sample exposed to $3 \mu \mathrm{M}$ cisplatin. The shaded area around each trace defines the standard error on the mean.
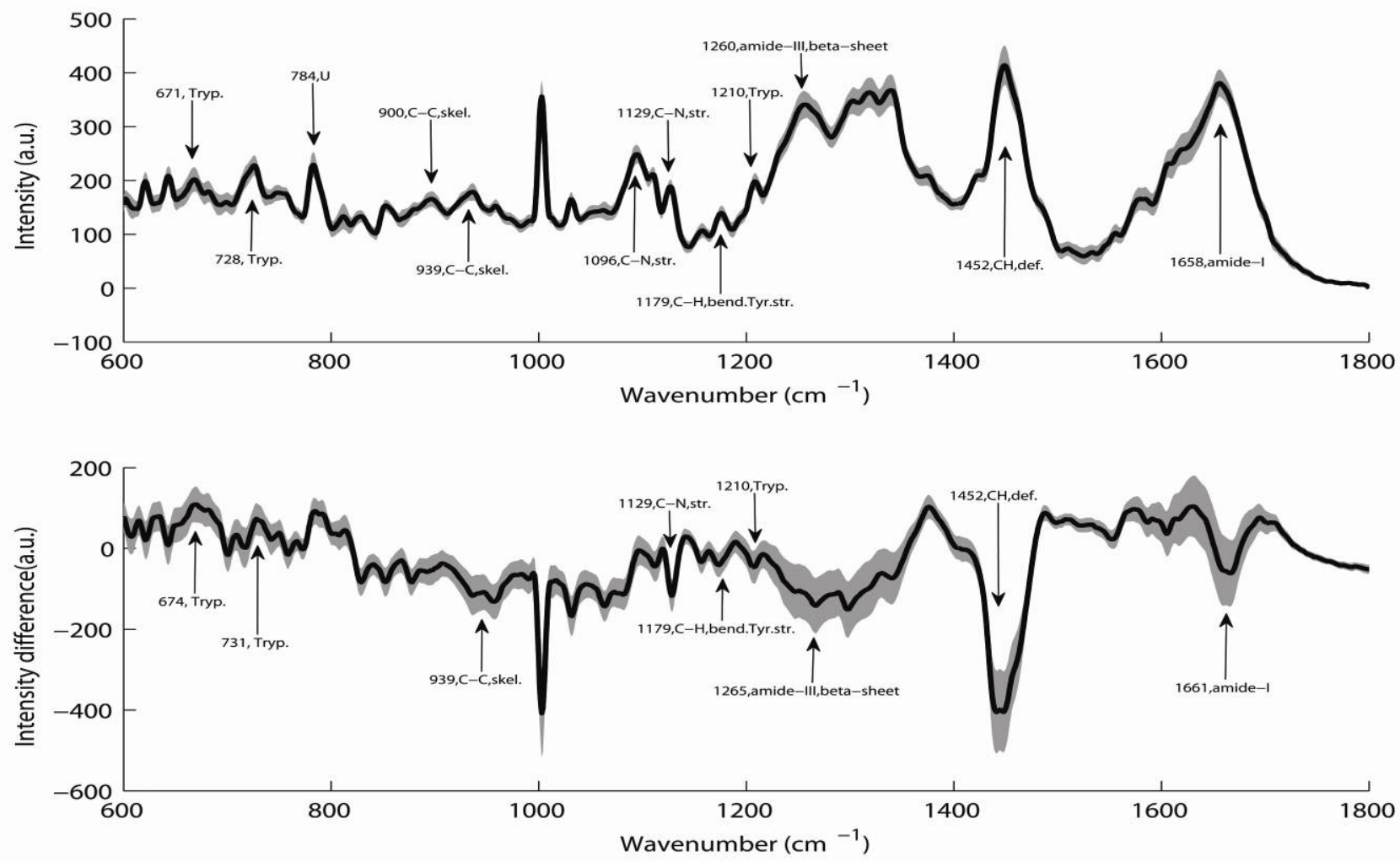

Figure 5: Mean spectrum of the cytoplasm of control sample (top) and the difference spectrum (bottom) between the mean of the control and the sample exposed to $3 \mu \mathrm{M}$ cisplatin. The shaded area around each trace defines the standard error on the mean. 
Figure 6. The major changes observed in the Raman bands include an increase in the intensities of the C-C skeletal stretching $\left(904 \mathrm{~cm}^{-1}, 935 \mathrm{~cm}^{-1}\right)$, phenyl alanine $\left(1001 \mathrm{~cm}^{-}\right.$ $\left.{ }^{1}\right)$, C-N stretching $\left(1061 \mathrm{~cm}^{-1}, 1131 \mathrm{~cm}^{-1}\right)$, Tyrosine ring ${ }_{5}$ breathing $\left(639 \mathrm{~cm}^{-1}, 961 \mathrm{~cm}^{-1}, 1199 \mathrm{~cm}^{-1}\right)$, Tryptophan ring breathing $\left(1011 \mathrm{~cm}^{-1}\right), \mathrm{CH}$ deformation $\left(1323 \mathrm{~cm}^{-1}\right.$ and $\left.1404 \mathrm{~cm}^{-1}\right)$ and $\mathrm{C}=\mathrm{C}$ bending $\left(1606 \mathrm{~cm}^{-1}\right)$.

It should be noted that the extract does not differentiate between membrane and cytoplasmic proteins and that the 10 in situ cellular environment is very different from that of the ex situ dried state, and thus that the spectral changes of figure 6 cannot be quantitatively compared to those observed in the cells. Nevertheless, the spectral changes in the protein extracted from cisplatin exposed compared to 15 control cell cultures confirms a significant modification of the protein structure as a result of the exposure, by direct or indirect means. Normally, in a cell, proteins are folded in a well-ordered structure and the side chains of the proteins are constrained ${ }^{34}$ and thus the intensities of these ${ }_{20}$ Raman bands are suppressed in the spectrum of the control as compared to the exposed. The increase in the intensities of these bands may be due to the direct binding of the cisplatin to the associated proteins which causes changes in their secondary structure and causes their unfolding, 25 exposing the phenylalanine/tyrosine/tryptophan side chains. These changes can be taken as the Raman signatures of the known action of the cisplatin binding to proteins in the cell membrane and cytoplasm ${ }^{19}$ of A549 cells. Moreover, changes in the amide-I band $\left(1660 \mathrm{~cm}^{-1}\right)$ 30 along with a shift (1660 to $1665 \mathrm{~cm}^{-1}$ ) and amide-III, $\beta$ sheet $\left(1252 \mathrm{~cm}^{-1}\right)$ along with a shift $\left(1252\right.$ to $\left.1257 \mathrm{~cm}^{-1}\right)$, are also observed. These two Raman bands are frequently used to allocate secondary structure to the proteins ${ }^{38}$ and the shifts observed in these bands can be the Raman 35 markers of the conformational changes in the associated proteins as a result of the action of the cisplatin.

The changes observed in the Raman spectra of the extracted proteins can also be identified in the mean control and difference spectra of the cell membrane or 40 cytoplasm or both albeit with slight deviations of their positions. Notably prominent in both are the bands related to C-C skeletal stretching (904 $\left.\mathrm{cm}^{-1}, 935 \mathrm{~cm}^{-1}\right), \mathrm{C}-\mathrm{N}$ stretching $\left(1131 \mathrm{~cm}^{-1}\right)$, Tyrosine ring breathing $\left(1199 \mathrm{~cm}^{-1}\right)$, $\mathrm{CH}$ deformation of the proteins $\left(1449 \mathrm{~cm}^{-1}\right)$, amide-I band $45\left(1660 \mathrm{~cm}^{-1}\right)$ and amide-III, $\beta$-sheet $\left(1252 \mathrm{~cm}^{-1}\right)$. These results confirm those obtained from the data of cell membrane and cytoplasm.

\section{Feature Selection by PLS Jack-knifing for the data of the Cell ${ }_{50}$ membrane}

For a fixed exposure concentration, the analysis of the mean difference spectra for cytoplasm and cellular membrane highlight the effects of the cellular interaction

55 with the cellular structures which can be the result of the direct chemical interaction of the agent or the resulting physiological (cytotoxic response). The former should be correlated with the applied dose, whereas the latter should be correlated with the physiological response (Figure 3). ${ }_{60}$ In an attempt to differentiate the responses, the spectral data, for each cellular region, over the whole exposure range, were subjected to a multivariate Partial Least Squares Regression (PLSR), using the chemical concentration and cytotoxicological response, respectively. ${ }_{65}$ The PLS Jack-knifing procedure was furthermore employed to identify the spectral features of maximum variance as a function of the respective parameters.

The regression co-efficients obtained by PLS-Jack knifing for the cell membrane data, regressed against cisplatin 70 concentration (Figure $7 \mathbf{A}$ ), give useful information regarding the signatures of the cisplatin attack on the cell membrane while entering the cell (chemical effect). As a result of interaction with the cisplatin, significant changes in the bands related to lipids at for example 1420-1426 cm ${ }_{75}{ }^{1}, 1436-1440 \mathrm{~cm}^{-1},\left(\mathrm{CH}_{3}\right.$ deformation $)$ and $1447-1466 \mathrm{~cm}^{-1}$ , 1474-1483 $\mathrm{cm}^{-1}$ (CH deformation) are observed, which may be indicative of the interaction of the cisplatin with the membrane lipids. Also, a positive shift of the band at $1449 \mathrm{~cm}^{-1}$, (C-H deformation) to $1466 \mathrm{~cm}^{-1}$ is observed in 80 the mean difference spectra, (Figure 3 B), On the basis of the information derived, it seems that cisplatin interacts with the membrane lipids and causes some changes in their structure. It has been reported by ${ }^{37}$ that cisplatin interacts with the membrane lipids which can cause neurotoxicity 85 and that this interaction with the lipid bilayer can cause an increase in the isotropic/hexagonal lipid phases at the cost of the lamellar phase.

Further changes at 713-717 $\mathrm{cm}^{-1}, 833-842 \mathrm{~cm}^{-1}, 1556-1563$ $\mathrm{cm}^{-1}$ associated with tryptophan ring breathing along with 90 the changes in the bands at $622-627 \mathrm{~cm}^{-1}, 852-860 \mathrm{~cm}^{-1}$, $1135-1147 \mathrm{~cm}^{-1}$ assigned to C-C stretching vibrations and $1122-1129 \mathrm{~cm}^{-1}, \quad 1161-1163 \mathrm{~cm}^{-1}$ assigned to $\mathrm{C}-\mathrm{N}$ stretching vibrations, $1485-1495 \mathrm{~cm}^{-1}$ (C-H deformation of proteins) are related to the proteins. Additionally, changes ${ }_{95}$ in the bands at $(1242-1244,1246-1255)$ assigned to amideIII $\beta$-sheets and at (1270-1316) of amide-III $\alpha$-helix and (1649-1652, 1659-1685) assigned to amide-I $\alpha$-helix are also observed. These changes can be attributed to the structural changes occurring in the proteins of the cell 100 membrane due to the attack of the drug, as also discussed in the information observed in the mean difference spectra of the cell membrane.

The regression co-efficients obtained by PLS-Jack knifing for the cell membrane data, regressed against cell viability ${ }_{105}$ (physiological effect), are shown in Figure 7 B. The bands of ring breathing of tryptophan $\left(711-736 \mathrm{~cm}^{-1}, 748-753\right.$ $\left.\mathrm{cm}^{-1}, 758-774 \mathrm{~cm}^{-1}\right)$, out plane ring breathing of tyrosine $\left(826-830 \mathrm{~cm}^{-1}\right)$, and C-C skeletal vibrations $\left(883-898 \mathrm{~cm}^{1}\right.$, 903-923, 928-931, 934-935) along with C-N stretching ${ }_{110}\left(1111-1116 \mathrm{~cm}^{-1}, 1120-1129 \mathrm{~cm}^{-1}\right)$ and $\mathrm{CH}_{2}$ rocking (740$744 \mathrm{~cm}^{-1}$ ) are related to proteins which can be attributed to the changes in the secondary and tertiary structures of the proteins due to the changes in the physiology of the cell and others in the stretching vibrations of the $\mathrm{C}-\mathrm{C}$ head 115 group of the lipids $\left(939-980 \mathrm{~cm}^{-1}\right), \mathrm{CH}$ deformation of the 

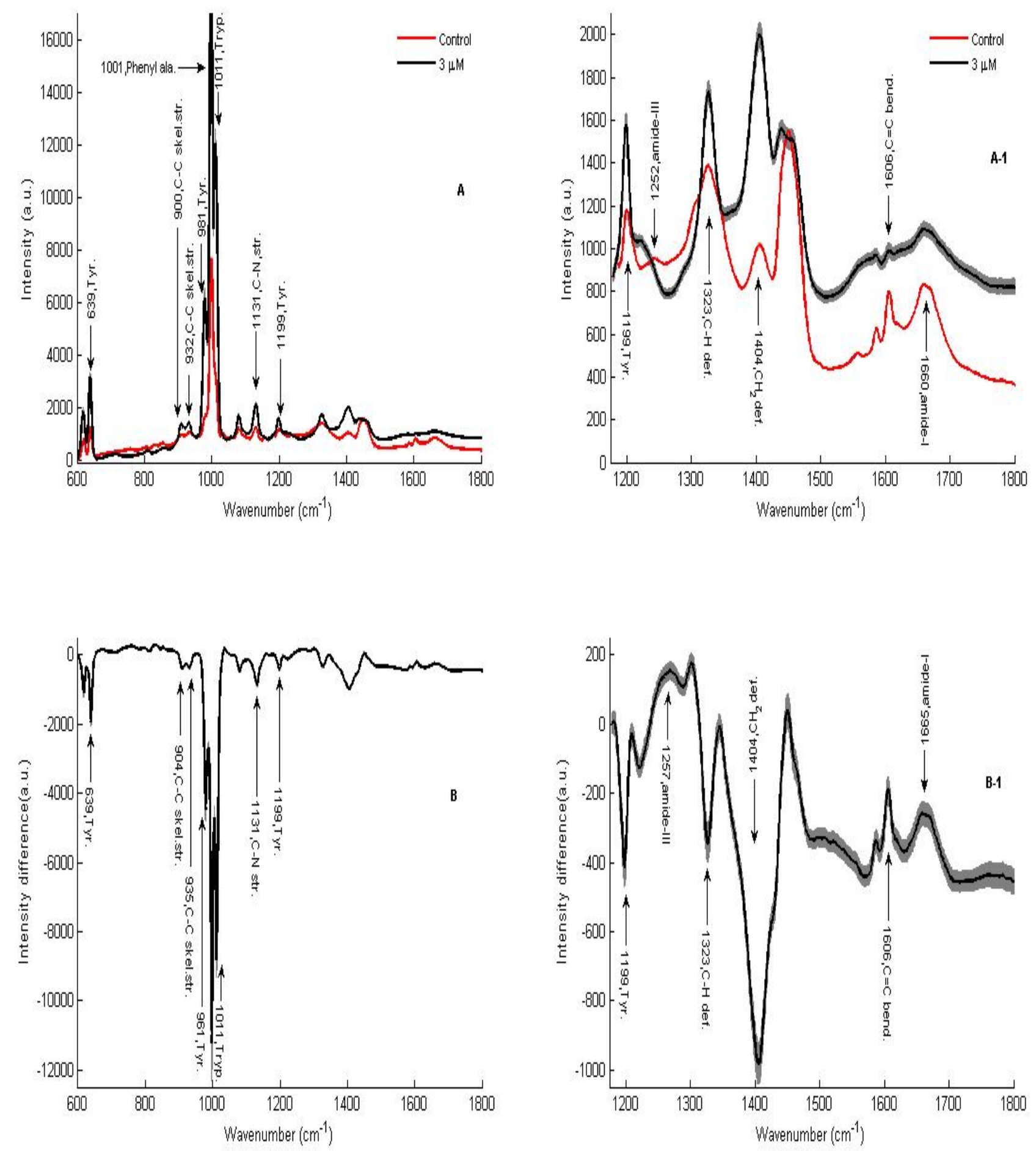

Figure 6: Raman spectra of protein extracted from A549 cells; Mean of the control and exposed to $3 \mu \mathrm{M}$ cisplatin for 96 hrs (A), the zoomed in region, 1199-1800, (A-1), difference spectra (B) and the zoomed in region, 1199-1800, (B-1). The shaded area defines the standard error on the mean. 

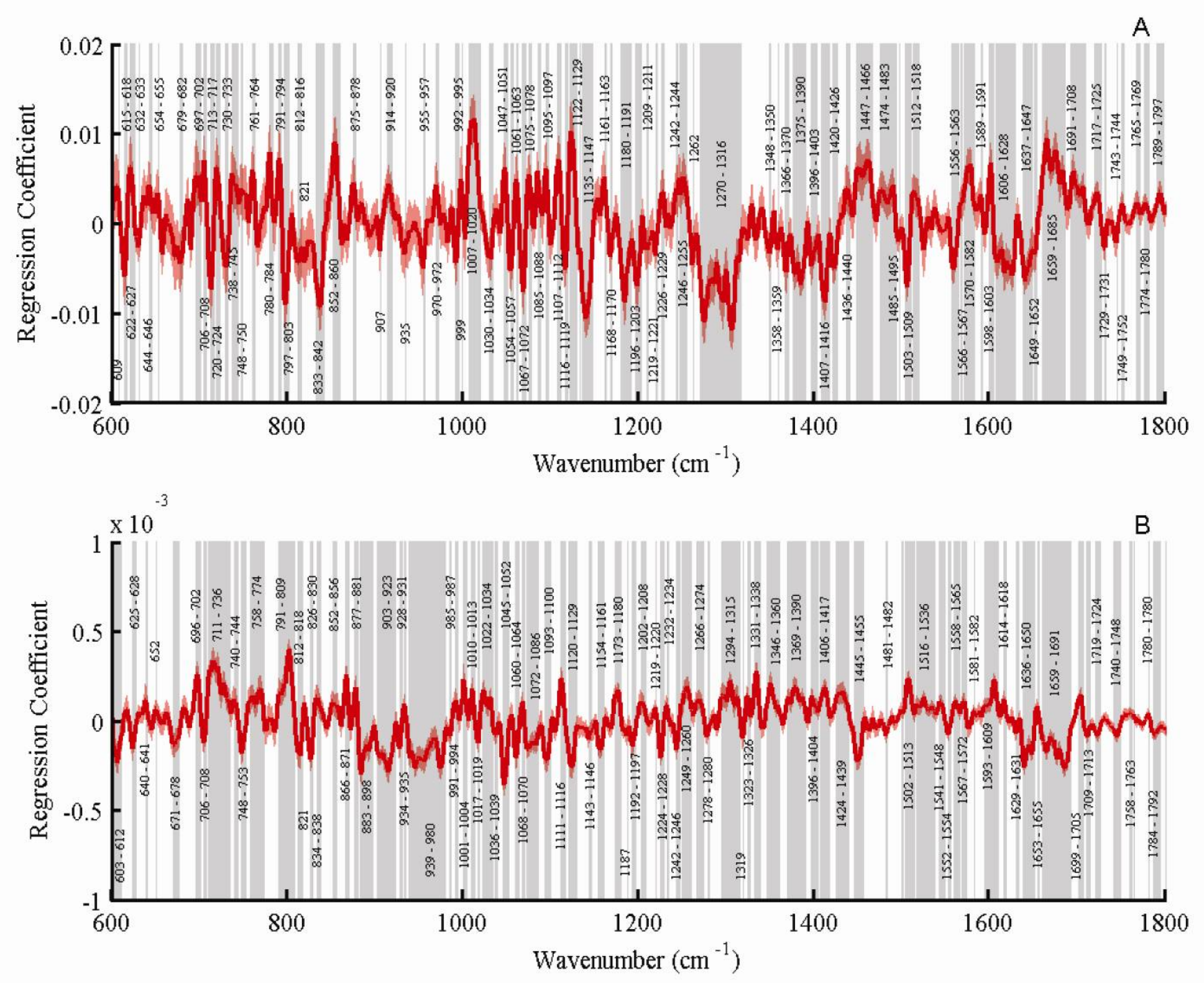

Figure 7: PLS-Jack knifing analysis, A (regressed against cisplatin concentrations) and B (regressed against cell viability) of the cell membrane spectra of A549 cells exposed to $0.05 \mu \mathrm{M}-50 \mu \mathrm{M}$ cisplatin for $96 \mathrm{hrs}$.

40 lipids (1424-1439 $\mathrm{cm}^{-1}, 1445-1455 \mathrm{~cm}^{-1}$ ), provide the Raman signatures of the structural changes in the membrane lipids as a result of the changes in the physiology (cell viability) of the cell.

Comparing the regression co-efficients obtained via ${ }_{45}$ spectral regression against cisplatin concentrations (which highlight the primary chemical effect of the action of the agent) with those obtained via regression against cell viability (which highlight biochemical markers of the change in the viability of the cell), very different spectral ${ }_{50}$ features are selected as being statistically significant and thus allow the differentiation of the chemotherapeutic response.

The spectral features which are changed only due to the chemical effect and not due to the physiological effect are 55 bands related to lipids $1270-1316 \mathrm{~cm}^{-1}\left(\mathrm{CH}_{2}\right.$ twist), 1420 $1426 \mathrm{~cm}^{-1}, \quad 1436-1440 \mathrm{~cm}^{-1}, \quad 1447-1466 \mathrm{~cm}^{-1}$ (C-H deformation) and bands related to proteins including 1485$1495 \mathrm{~cm}^{-1}$ (C-H deformation of proteins), (713-717 $\mathrm{cm}^{-1}$, $833-842 \mathrm{~cm}^{-1}, 1556-1563 \mathrm{~cm}^{-1}$ ) of tryptophan ring breathing among others. This may indicate that the chemical interaction of the cisplatin with the membrane 100 proteins and lipids results in disintegration of the lipids and changes in the conformation of the membrane proteins.

On the other hand, the spectral features which are changed only due to the physiological effect and not due to the chemical effect are related mainly to the proteins of the 105 cell membrane $877-881 \mathrm{~cm}^{-1}$ (Glutamine residues), 883$898 \mathrm{~cm}^{-1}$, 903-923 $\mathrm{cm}^{-1}$, 928-931 cm $\mathrm{cm}^{-1}$, (C-C skeletal stretching), $958-987 \mathrm{~cm}^{-1}$ (C-C skeletal $\beta$-sheets) which may be due to the membrane protein signalling as a result of the attack and action of the cisplatin on the cell 110 membrane.

\section{Feature Selection by PLS Jack-knifing for the data from Cytoplasm}

${ }_{115}$ For the cytoplasm data, the regression co-efficients obtained by PLS-Jack knifing, are shown, for regression against cisplatin concentrations (Figure $8 \mathrm{~A}$ ) and against cell viability (Figure 8 B). 
As a result of the chemical effect (Figure 8 A), features primarily related to proteins are identified. In addition to the observations of the same Raman bands for proteins as 5 observed in the mean difference spectra (Figure 4 B), Jack knifing results for cytoplasm data show that there is a positive shift of the amide I band from $1664 \mathrm{~cm}^{-1}$ to 1676 $\mathrm{cm}^{-1}$ with increasing cisplatin concentration, which may be indicative of the changes in the secondary and tertiary 10 structure of the protein.

The regression against the cell viability (Figure 8 B) shows features related to the change in the cell physiology due to the action of the cisplatin and include tryptophan ring breathing (714-715 $\left.\mathrm{cm}^{-1}, 724-727 \mathrm{~cm}^{-1}, 764 \mathrm{~cm}^{-1}\right), \mathrm{CH}$ 15 bending (1390-1393) and also, ribose ring breathing of the RNA $\left(1057 \mathrm{~cm}^{-1}\right)$ and many others which are highlighted. The changes which are seen only due to the chemical effect and not due to the physiological effect include bands assigned to out of plane ring breathing of tyrosine $\left(824 \mathrm{~cm}^{-}\right.$ ${ }_{20}{ }^{1}$ ), related to $\mathrm{C}-\mathrm{C}$ stretching vibrations $\left(862 \mathrm{~cm}^{-1}\right), \mathrm{C}-\mathrm{N}$ stretching (1073-1074 $\left.\mathrm{cm}^{-1}\right), \mathrm{C}-\mathrm{C}$ stretching related to skeletal changes of proteins.

On the other hand, the changes which are seen only due to the physiological effect and not due to the chemical effect ${ }_{25}$ are related to tryptophan ring breathing $\left(714-715 \mathrm{~cm}^{-1}\right.$, $\left.724-727 \mathrm{~cm}^{-1}, 764 \mathrm{~cm}^{-1}\right), \mathrm{CH}$ bending $\left(1390-1393 \mathrm{~cm}^{-1}\right)$ and also, ribose ring breathing of the RNA $\left(1057 \mathrm{~cm}^{-1}\right)$.

PLS-model for the prediction of levels of the exposures and 30 cellular viability

CRM can clearly fingerprint the effects of the interaction of the chemotherapeutic agent within the cellular regions and identify that fingerprint within the cellular spectra of ${ }_{35}$ exposed cells. PLSR models of A549 cellular membrane and cytoplasmic spectra versus concentration and viability measurements from the MTT assay were constructed to determine the ability of the Raman spectral data to predict the level of exposure to cisplatin and the resultant 40 physiological effect.

For the construction of the PLSR model, all spectra of each cellular region were compiled into a matrix, and were randomly sorted. A total of $60 \%$ of the spectra were used to train the PLSR regression model and $40 \%$ of the total ${ }_{45}$ was retained as an independent test set to assess the performance of the model in predicting the level of exposure, and the cellular viability, with unseen data. Leave-one out cross validation with the calibration set was used to determine the optimal model complexity for use in 50 testing ${ }^{26}$. This process was performed on fifty separate occasions, with randomization of the data matrix and splitting of the data on each occasion to prevent data bias 24. The reliability/uncertainty of the model can be determined from the results from the values of the root 55 mean square error of calibration (RMSEC) and the root mean square error of prediction (RMSEP). Control of overfitting was achieved using a procedure previously described by Martens and $\mathrm{Naes}^{39}$. The procedure involves selection of the optimal number of latent variables to retain 60 within the PLS model via ten-fold cross-validation with the calibration data set. The optimal number of LV's was then selected on the basis of the number which provided the lowest root mean squared error at cross validation.

An example of the results of the PLSR model prediction of ${ }_{65}$ the cellular viability for the cell membrane data is shown in Figure 9, where the values of the root mean square error of calibration (RMSEC) and the root mean square error of prediction (RMSEP) denote the prediction uncertainty. The mean values of the RMSEC and RMSEP for the PLSR for 70 prediction of the level of exposure to cisplatin (from the spectra of cell membrane) were found to be $3.01 \mu \mathrm{M}$ and $4.74 \mu \mathrm{M}$ respectively. The associated values of RMSEC and RMSEP for PLSR against normalized cellular viability were 0.06 and 0.12 respectively. The RMSEP for 75 prediction of cisplatin concentration is therefore $9.48 \%$ over the full scale range ( 0 to $50 \mu \mathrm{M})$, and $12 \%$ over the full scale range of viability (from 0 to 1 ).

The mean values of the RMSEC and RMSEP for the PLSR for prediction of the level of exposure to cisplatin (from ${ }_{80}$ the spectra of cytoplasm) were found to be $1.47 \mu \mathrm{M}$ and $3.74 \mu \mathrm{M}$ respectively. The associated values of RMSEC and RMSEP for PLSR against normalized cellular viability were 0.07 and 0.14 respectively. The RMSEP for prediction of cisplatin concentration is therefore $7.48 \%$ ${ }_{85}$ over the full scale range $(0$ to $50 \mu \mathrm{M})$, and $14 \%$ over the full scale range of viability (from 0 to 1 ).

In the previous study of the nuclear spectra of the same system, the mean values of the RMSEC and RMSEP for the PLSR for prediction of the level of exposure to ${ }_{90}$ cisplatin were found to be $1.67 \mu \mathrm{M}$ and $3.41 \mu \mathrm{M}$ respectively. The associated values of RMSEC and RMSEP for PLSR against normalized cellular viability were 0.05 and 0.11 respectively. The RMSEP for prediction of cisplatin concentration is therefore $6.8 \%$ over 95 the full scale range $(0$ to $50 \mu \mathrm{M})$, and $11 \%$ over the full scale range of viability (from 0 to 1 ).

Furthermore, the spectral data from cell membrane, cytoplasm and nucleus was combined and a PLSR model was constructed to predict the level of exposure and oo cellular viability on the basis of the combined spectral changes. The values of the RMSEC and RMSEP for PLSR for prediction of level of exposure were found to be 6.44 and $8.15 \mu \mathrm{M}$ and against the normalised cellular viability 0.148 and 0.186 respectively. The RMSEP for prediction 105 of cisplatin concentration is therefore $16.3 \%$ over the full scale range ( 0 to $50 \mu \mathrm{M})$, and $18.6 \%$ over the full scale range of viability (from 0 to 1 ).

Table 1 summarises the prediction accuracies of the PLSR models based on the individual cellular components as 110 well as the combined data, for regression against both the cisplatin dose and the cell viability. Figures in brackets denote standard deviations. In all cases, higher prediction 

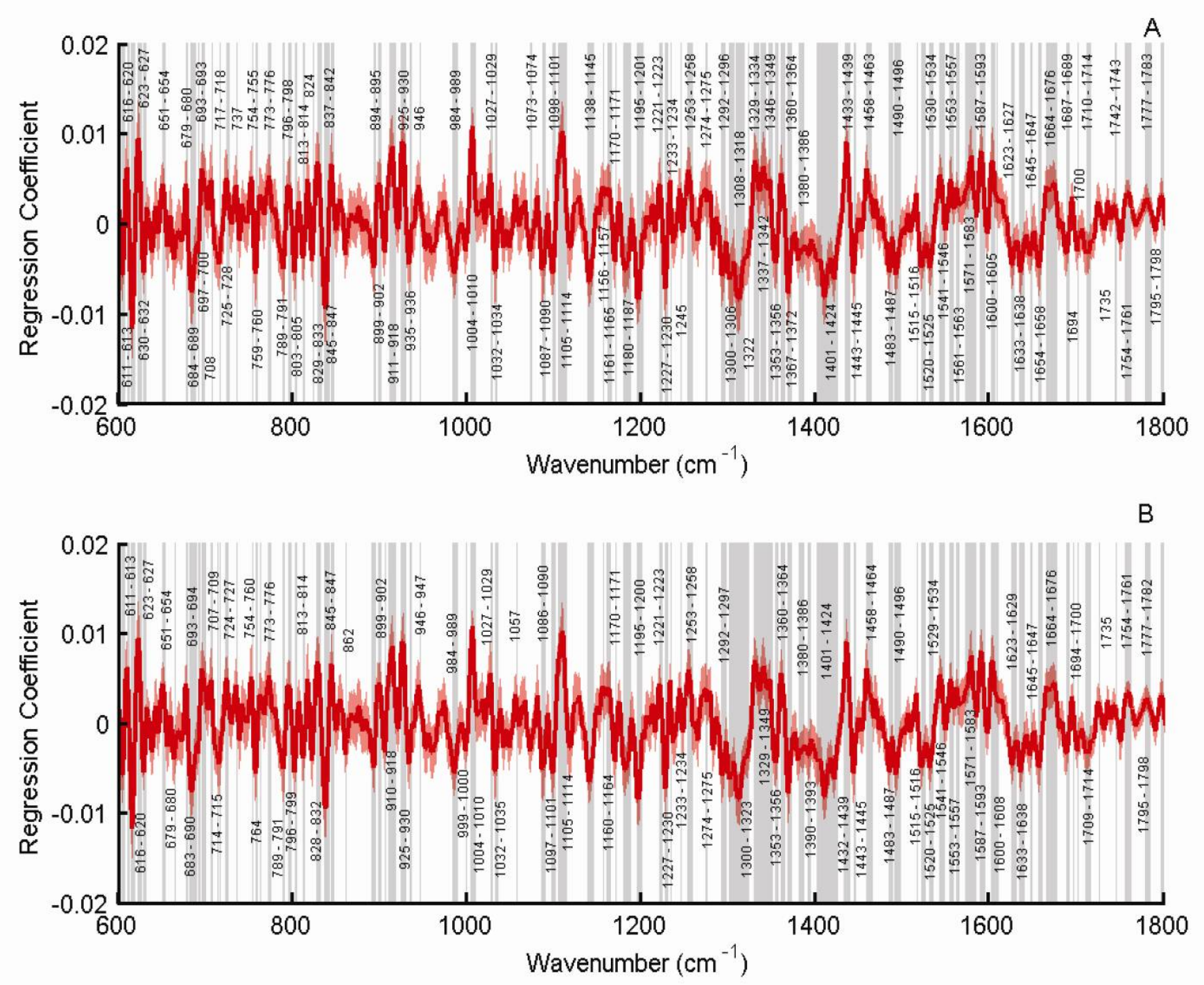

Figure 8: PLS-Jack knifing analysis, A (regressed against cisplatin concentrations) and B (regressed against cell viability) of the cytoplasm spectra of A549 cells exposed to $0.05 \mu \mathrm{M}-50 \mu \mathrm{M}$ cisplatin for $96 \mathrm{hrs}$.

accuracy is found for regression against the cisplatin dose, and for both regression against dose and physiological response, nuclear data yields higher precision.

5 As cisplatin primarily interacts with DNA in the nucleus, the largest effects of the agent are manifest there, either due to the direct chemical interaction of the drug or due to the physiological response of the cell to it. This may be the reason why the PLSR model gives the highest prediction 10 accuracies for both the level of exposure and cell viability, for the nuclear data.

It should further be noted that PLSR is a linear model, and is thus limited for a nonlinear response. In operational models of pharmacological agonism, the relationship is between the agonist concentration and that of receptors occupied by the agonist is in itself a hyperbolic function ${ }^{40}$ and thus it may be expected that the direct chemical effect as a result of the interaction of cisplatin with nuclear DNA
20 or other subcellular molecular components, as monitored by Raman spectroscopy is not a linear function. The dependence of the physiological effects on the agonist concentration is a further complex function, as a result of the ensuing biochemical cascades, but is generally ${ }_{25}$ described by the operational equation employed to fit the cytotoxicity data of Figure 3. It may be expected therefore that a regression of the spectral data against the physiological effect as expressed by the cell viability should yield a more precise result. However, it has been 30 demonstrated for the case of low dose radiation responses in cellular systems, that the spectral responses are not linearly dependent on the physiological responses as measured by cytoxicological assays ${ }^{41}$ Furthermore, it may be expected that the cascade of biochemical process 35 introduces an increasing degree of variability into the measured response. In the development of spectroscopic 

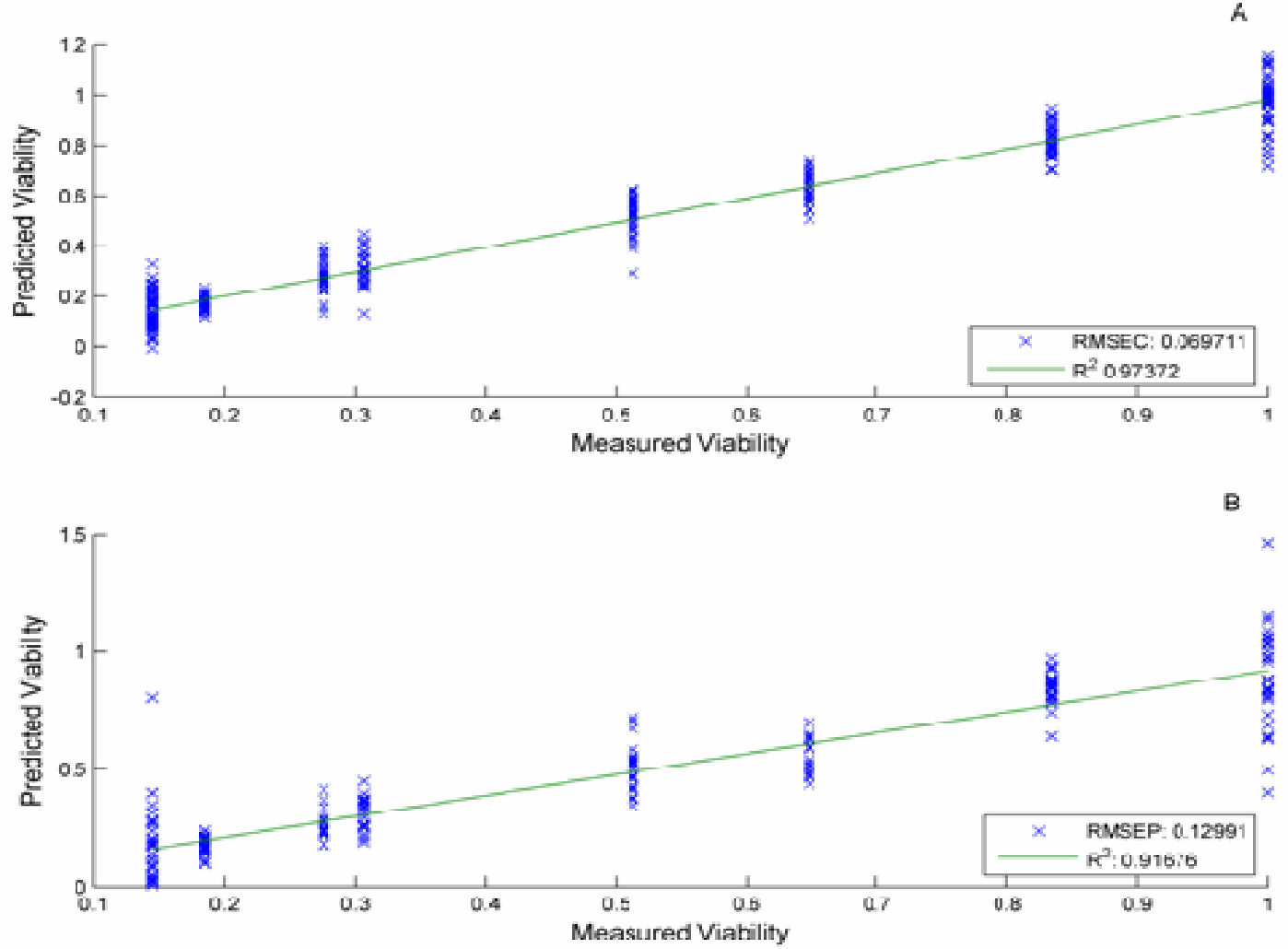

Figure 9: Calibration (A) and test set performance (B) in prediction with PLSR of the cell viability using Raman spectra of the cell membrane of A549 cells. The root mean squared errors of calibration (RMSEC) and prediction (RMSEP) are in the units of cell viability, which themselves are normalized to the level in the control.

\begin{tabular}{|l|l|l|l|l|l|l|}
\hline Type of spectral data & \multicolumn{2}{|c|}{ RMSEC } & \multicolumn{2}{c|}{ RMSEP } & \multicolumn{2}{c|}{ error of prediction } \\
\hline & $\begin{array}{l}\text { Conc. } \\
(\mu \mathrm{M})\end{array}$ & Viability & $\begin{array}{l}\text { Conc. } \\
(\mu \mathrm{M})\end{array}$ & Viability & Conc. & Viability \\
\hline Nucleus & $1.7(0.5)$ & $0.05(0.01)$ & $3.4(0.4)$ & $0.11(0.01)$ & $\begin{array}{l}6.8 \\
(0.8)\end{array}$ & $\begin{array}{l}11 \\
(1)\end{array}$ \\
\hline Cytoplasm & $1.5(0.4)$ & $0.07(0.02)$ & $3.7(0.5)$ & $0.14(0.01)$ & $\begin{array}{l}7.5 \\
(0.9)\end{array}$ & $\begin{array}{l}14 \\
(1)\end{array}$ \\
\hline Membrane & $3.0(0.3)$ & $0.06(0.02)$ & $4.7(0.5)$ & $0.12(0.01)$ & $\begin{array}{l}9.5 \\
(0.9)\end{array}$ & $\begin{array}{l}12 \\
(1)\end{array}$ \\
\hline Combined data & $6.4(0.2)$ & $0.15(0.01)$ & $8.2(0.4)$ & $0.19(0.01)$ & $\begin{array}{l}16.3 \\
(0.9)\end{array}$ & $\begin{array}{l}19 \\
(1)\end{array}$ \\
\hline
\end{tabular}

Table 1: Prediction accuracies of the PLSR models based on the individual cellular components as well as the combined data, for regression against 95 both the cisplatin dose and the cell viability. Figures in brackets denote standard deviations.

techniques for biochemical and biomedical applications, the analysis of model systems such as the action of cis${ }_{100}$ platin in vitro and comparison to parallel gold standard cytological assays is crucial. Ultimately, a more flexible nonlinear model is desirable, whereby the spectral data can be regressed against a user definable function. The results demonstrate Raman spectroscopy is a powerful 105 tool to explore the molecular basis of the action of chemotherapeutic agents in vitro. As well as elucidating the mechanisms of interaction, the regression models can be employed in a predictive capacity. These findings also suggest that the technique should be applied to the 110 spectral data from each component of the cell separately in order to increase the accuracy in the prediction of level of exposure and viability of the cell on the basis of the spectral changes. It should be noted that the cell 
cultures were not synchronised according to cell cycle in this study. Synchronisation of the cells could be employed to further minimise the cellular variability, but also to explore the susceptibility of the cells to the drug 5 as a function of cell cycle. ${ }^{42,43}$

\section{\$Acknowledgements}

${ }_{10}$ The authors acknowledge funding through the Technology Sector Research (Strand III) programme of the Irish Higher Education Authority and the Irish HEA Programme for Research in Third Level Institutions, Cycle 4 National Biophotonics and Imaging Platform for 15 Ireland (NBIPI).

\section{References}

1. F. M. Lyng, E. O. Faolain, J. Conroy, A. D. Meade, P.

$20 \quad$ Knief, B. Duffy, M. B. Hunter, J. M. Byrne, P. Kelehan and H. J. Byme, Experimental and Molecular Pathology, 2007, 82, 121-129.

2. J. Chan, S. Fore, S. Wachsman-Hogiu and T. Huser, Laser Photon. Rev., 2008, 2, 325-349.

$253 . \quad$ T. Huser, C. A. Orme, C. W. Hollars, M. H. Corzett and R. Balhorn, J. Biophotonics, 2009, 2, 322-332.

$4 . \quad$ P. Knief, C. Clarke, E. Herzog, M. Davoren, F. M. Lyng, A. D. Meade and H. J. Byrne, 2009.

5. A. D. Meade, C. Clarke, F. Draux, G. D. Sockalingum, M.

30 Manfait, F. M. Lyng and H. J. Byrne, Anal. Bioanal. Chem., 2010, 396, 1781-1791.

6. C. A. Owen, J. Selvakumaran, I. Notingher, G. Jell, L. L. Hench and M. M. Stevens, Journal of Cellular Biochemistry, 2006, 99, 178-186.

$357 . \quad$ F. Bonnier, P. Knief, B. Lim, A. D. Meade, J. Dorney, K. Bhattacharya, F. M. Lyng and H. J. Byrne, Analyst, 2010, 135, 3169-3177.

8. M. Miljkovic, T. Chernenko, M. J. Romeo, B. Bird, C. Matthaus and M. Diem, Analyst, 2010, 135, 2002-2013.

$409 . \quad$ J. Y. Ling, Q. Z. Yang, S. S. Luo, Y. Li and C. K. Zhang, Chinese Chemical Letters, 2005, 16, 71-74.

10. J. Ling, S. D. Weitman, M. A. Miller, R. V. Moore and A. C. Bovik, Applied optics, 2002, 41, 6006-6017.

11. I. Notingher, C. Green, C. Dyer, E. Perkins, N. Hopkins, C. $45 \quad$ Lindsay and L. L. Hench, Journal of the Royal Society Interface, 2004, 1, 79-90.

12. S. Verrier, I. Notingher, J. M. Polak and L. L. Hench, 2004.

13. H. Nawaz, F. Bonnier, P. Knief, O. Howe, F. M. Lyng, A. D. Meade and H. J. Byrne, Analyst, 2010, 135, 3070-3076.

$5014 . \quad$ C. P. Belani, Seminars in Oncology, 2004, 31, 25-33.

15. D. G. Haller, Seminars in Oncology, 2004, 31, 10-16.

16. F. M. Muggia, Seminars in Oncology, 2004, 31, 17-24.

17. M. A. Szczepanski, A. Grzanka, A. Litwiniec, L. Gackowska, I. Kubiszewska and D. Grzanka, Cell Biology
G. Speelmans, R. Staffhorst, K. Versluis, J. Reedijk and B. deKruijff, Biochemistry, 1997, 36, 10545-10550.

M. Akaboshi, K. Kawai, H. Maki, K. Akuta, Y. Ujeno and T. Miyahara, Japanese Journal of Cancer Research, 1992, 83, 522-526.

R. P. Perez, European Journal of Cancer, 1998, 34, 15351542 .

B. Kosmider, I. Wojcik, R. Osiecka, J. Bartkowiak, E. Zyner, J. Ochocki and P. Liberski, Investigational New Drugs, 2005, 23, 287-297.

T. Mosmann, Journal of Immunological Methods, 1983, 65 , 55-63.

F. E. Grubbs, Technometrics, 1969, 11, 1-\&.

K. Varmuza and P. Filzmoser, Introduction to Multivariate Statistical Analysis in Chemometrics, CRC Press, Taylor and Francis Group, Boca Raton, FL, 2009. H. Martens and M. Martens, 2000.

A. D. Meade, C. Clarke, H. J. Byrne and F. M. Lyng, Radiation research, 2010, 173, 225-237.

F. Westad and H. Martens, Journal of near Infrared Spectroscopy, 2000, 8, 117-124.

J. De Gelder, K. De Gussem, P. Vandenabeele and L. Moens, J. Raman Spectrosc., 2007, 38, 1133-1147.

P. R. T. Jess, V. Garces-Chavez, D. Smith, M. Mazilu, L. Paterson, A. Riches, C. S. Herrington, W. Sibbett and K. Dholakia, Optics Express, 2006, 14, 5779-5791.

A. D. Meade, F. M. Lyng, P. Knief and H. J. Byrne, Anal Bioanal Chem, 2007, 387, 1717-1728.

I. Notingher, Sensors, 2007, 7, 1343-1358.

I. Notingher, S. Verrier, S. Haque, J. M. Polak and L. L. Hench, Biopolymers, 2003, 72, 230-240.

F. Draux, P. Jeannesson, A. Beljebbar, A. Tfayli, N. Fourre, M. Manfait, J. Sule-Suso and G. D. Sockalingum, Analyst, 2009, 134, 542-548.

C. G. Xie, C. Goodman, M. A. Dinno and Y. Q. Li, Optics Express, 2004, 12, 6208-6214.

E. Ulukaya, F. Ozdikicioglu, A. Y. Oral and M. Demirci, Toxicology in Vitro, 2008, 22, 232-239.

N. Cordes, C. Beinke, L. Plasswilm and D. van Beuningen, Strahlentherapie Und Onkologie, 2004, 180, 157-164.

M. Jensen and W. Nerdal, European Journal of Pharmaceutical Sciences, 2008, 34, 140-148.

J. T. Pelton and L. R. McLean, Analytical Biochemistry, 2000, 277, 167-176.

H. Martens and T. Naes, Multivariate Calibration, John Wiley and Sons, 1994.

J. W. Black and P. Leff, Proceedings of the Royal Society of London Series B-Biological Sciences, 1983, 220, 141-162.

A. D. Meade, PhD thesis, Dublin Institute of Technology, 2010.

H. Y. Jiao, S. L. Allinson, M. J. Walsh, R. Hewitt, K. J. Cole, D. H. Phillips and F. L. Martin, Mutagenesis, 2007, 22, 111-116.
V. Llabjani, K. C. Jones, G. O. Thomas, L. A. Walker, R. F. Shore and F. L. Martin, Environ. Sci. Technol., 2009, 43, 3356-3364. 